\title{
Incubation-habit in a Phyllodocid Polychæte, Notophyllum foliosum Sars.
}

By

Yô K. Okada.

With 1 Figure in the Text.

Tнат a mother worm protects its eggs until the young are hatched is common enough among Polychætes, but not in the family Phyllodocidæ.

McIntosh (1908) mentioned in his British Annelids, Vol. II, Pt. I, p. 49, that two female specimens of Notophyllum foliosum, procured by his late friend Dr. Howden, at Lamlash, Arran, in August, were laden with mature eggs. Certainly the words "were laden " used here tell us something about the particular habit of the worm, but the sentence is too short and is not emphatic enough to attract attention. Hence his observation has remained without being noticed at all.

Using the opportunity of my stay at Plymouth, I have always paid attention to Notophyllum found among dredgings, and have carefully examined the specimens obtained, with the hope of proving McIntosh's statement. I was lucky enough to obtain two female specimens laden with eggs, and I am very glad to be able to prove the incubation habit in this Phyllodocid Polychæte. The accompanying figure shows one of these specimens mounted in Canada balsam.

This specimen was found in September, 1927, in an abandoned tube of Serpula, and measured about $12 \mathrm{~mm}$. It consisted of fifty-six setigerous segments succeeded as usual by a pygidium. The dorsal cirri are exceedingly broad, which is a generic character, and they cover almost the entire dorsal surface of the body, overlapping one another on both sides. The lamellæ in the fresh condition are somewhat fleshy, soft, and rather yellowish in colour, with dark brown pigment round the edge.

When these broad dorsal lamellæ were turned forwards (or anteriorly), a mass of cream-like, yellow gelatinous substance came to light near the posterior end of the worm. A piece of this mass was isolated, and then brought under the microscope, which disclosed a large number of developing eggs, agglutinated together in a band or ribbon. The length of the entire band or ribbon extended from the 38th to the 47th setigerous segment or a little beyond these segments, and the band was fixed at both ends to the dorsal surface of segments $41-45$ and 
coiled in between these fixed points (see fig. 1). There was another small mass of the eggs attached near the level of the 15th setigerous

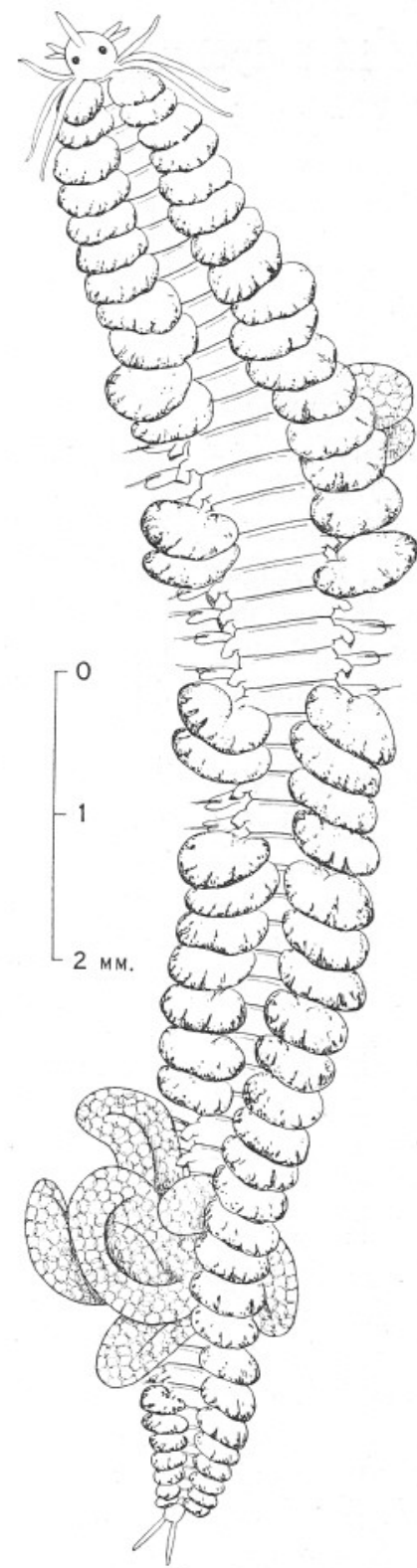

FIG. 1. segment, but in the second specimen such an anterior mass was not found. In other respects the incubation habit was the same in both cases.

Without further description, it is easily understood that the method of incubation is the same or at least closely related to that of Polynoids. Harmothoe imbricata, a common Polychæte on both the English and French sides of the Channel, lives also in Japan, and there the worm incubates, protecting the eggs under the broad dorsal cirri or elytra, as they are called. According to A. Izuka (1912, p. 48), the breeding season of the Polychæte (at Misaki ?) is in "the months of March and April"; "the eggs are agglutinated together by a transparent mucous secretion," but not in the shape of a ribbon, and are carried under the elytra, from the 8th to the penultimate segment. The only difference to be found in this case is that the egg-masses do not form ribbons, and a greater number of segments is concerned in the phenomenon.

P. Fauvel (1916, p. 426) gives another example of a Polynoid showing the incubation habit in Polynoë antarctica from the Falklands. ("Sous les élytres, sont accumulés des œufs qui y paraissent incubés.")

The method of incubation in the Polynoids is evidently a special utilization of the space produced between the broadened dorsal cirri and the dorsal surface of the worm, but we are entirely ignorant as to why only a very limited number of species utilize this space for the special purpose of incubation.

In the Falklands collection Fauvel (l.c., p. 448) finds a specimen of Cirratulus cirratus in a tube 
of Potamilla buried in the tissues of a sponge, protecting larvæ $2 \mathrm{~mm}$. long. ("Ses branchies et ses filets tentaculaires, rabattus sur le dos et fortement emmelés, y retiennent une masse assez considérable de jeunes larves de $2 \mathrm{~mm}$. de longueur, ne possédant encore que douze sétigères.") According to Ch. Gravier (1923, p. 179), this Polychæte does not incubate its eggs on the French side of the Channel, and I think perhaps not on the English side either. The incubation habit in this case of Cirratulus may be due to the low temperature at the Falk. lands, but the same analogy cannot be extended to the case of Polynoids, since at Misaki, Japan, where Harmothoë imbricata incubates, the water is by no means colder than in the English Channel.

If, on the other hand, the habit in question is a chance happening in certain Polynoids to utilize the comparatively wide space between the dorsal lamellæ and the surface of the body for the purpose of protecting the young, it would be little astonishing to find the same or at least a similar habit independently developed in Polychætes of another family having a similar differentiation of the dorsal cirri, and also utilizing the same space for the same purpose. The incubation-habit in Notophyllum would be of this nature, its origin, independent of, but closely related to the same habit of Polynoids. As mentioned by Gravier (l.c.), this method of incubation is the most primitive type among Polychætes.

\section{REFERENCES.}

Fauvel, P. 1916. Annélides Polychètes des îles Falkland recueilles par M. Rupert Vallentin, Esq. (1902-1910). Arch. Zool. expér. et gener. T. 55 .

Gravier, Ch. 1923. La Ponte et l'Incubation chez les Annélides Polychètes. Ann. Sc. Nat. (Zool.). S. 10e, t. 6 .

Izuka, A. 1912. The Errantiate Polychæta of Japan. Journ. Coll. Sci., Tokyo, Vol. 30.

McIntosh, W. C. 1908. The British Annelids. Vol. II, Pt. 1, Ray Society. 
